\title{
Raman Characterization of Oxidation Behavior of Free Carbon in Silicon Oxycarbide Ceramics
}

\author{
Manabu FUKUSHIMA, ${ }^{\dagger}$ Eiichi YASUDA, Yoshikazu TERANISHI, \\ Kazumasa NAKAMURA and Yasuhiro TANABE \\ Materials \& Structures Laboratory, Tokyo Institute of Technology, 4259, Nagatsuta, Midori-ku, Yokohama-shi 226-8503
}

\section{シリコンオキシカーバイドセラミックス中の遊離炭素の酸化挙動のラマン分光法による解析 福島 学 ${ }^{\dagger} \cdot$ 安田榮一·寺西義一 · 中村和正 ·田邊靖博 \\ 東京工業大学応用セラミックス研究所構造デザイン研究センター, 226-8503 横浜市緑区長津田 4259}

\begin{abstract}
Tantalum and niobium containing silicon oxycarbide ceramics were prepared from hybrid gels through cohydrolysis with methyltriethoxysilane and pentaethoxyniobium/tantalum, and pyrolysis at $1000^{\circ} \mathrm{C}$. To investigate the behavior of free carbon in $\mathrm{Si}-\mathrm{Nb}-\mathrm{C}-\mathrm{O}$ and $\mathrm{Si}-\mathrm{Ta}-\mathrm{C}-\mathrm{O}$ ceramics, Raman spectroscopy was used. The spectra obtained before oxidation showed a higher shift of the $G$ band at around approximately $1610 \mathrm{~cm}^{-1}$, which means a cumulative band of $G$ and $D^{\prime}$. After oxidation, however, a symmetric $G$ band, the shift toward a normal position at $1580 \mathrm{~cm}^{-1}$ and a weaker background were detected. These phenomena were found to strongly correlate with the oxidation of carbon reactive sites, i.e., those of radical and edge carbon species in tiny graphene layer of free carbon.

[Received June 21, 2004; Accepted August 20, 2004]
\end{abstract}

Key-words : Organic-inorganic hybrid, Sol-gel route, Shaped silicon oxycarbide ceramics, Oxidation, Raman spectroscopy

\section{Introduction}

Silicon oxycarbide $(\mathrm{Si}-\mathrm{C}-\mathrm{O})$ ceramics are prepared through a sol-gel transition and pyrolysis process. The authors have already reported the preparation of $\mathrm{Si}-\mathrm{Nb}-\mathrm{C}-\mathrm{O}$ and $\mathrm{Si}-\mathrm{Ta}-$ $\mathrm{C}-\mathrm{O}$ ceramic films from hybrids and their oxidation behavior by X-ray photoelectron spectroscopy (XPS). ${ }^{1) 2}$ The pyrolysis of the hybrids leads to the cleavage of organic groups at approximately $600^{\circ} \mathrm{C}$ and subsequent carbonization with the evolution of hydrogen and hydrocarbon groups from 600$1000^{\circ} \mathrm{C}^{3)-5)}$ The free carbon formed through the pyrolysis is encapsulated in silica and silicon oxycarbide phases, resulting in the resistance to oxidation because of the limitation of oxygen diffusion. Thus, ceramics without a residual organic group show improved antioxidation characteristics, even when a large amount of free carbon is contained in the ceramics. ${ }^{6}$

Soraru reported that the shape of oxycarbide ceramics is important for high-temperature applications, with their bulk and plate shapes being more desirable for thermal stability than those of thin films such as coating film. ${ }^{7)}$ However, the heat treatment of hybrids for obtaining shaped bulk ceramics results in the usual cracking problems. We have developed large crack-free self-supported ceramic films by the pyrolysis of niobium- and tantalum-containing hybrid gel. ${ }^{1), 2}$ Additionally, oxidation tests under more severe conditions such as a lower oxidative heating rate should be carried out because shaped ceramics such as plate and self-supported films have resistance to oxidation.

Studies on the oxidation of free carbon in oxycarbide ceramics still remained their weight loss by thermogravimetric

\footnotetext{
† Now with AIST, National Institute of Advanced Industrial Science and Technology, 2266-98, Shimo-Shidami, Moriyama-ku, Nagoyashi, Aichi 463-8560

現在 : 独立行政法人産業技術総合研究所先進製造プロセス研究部 門高性能部材化プロセス研究グループ，463-8560 名古屋市守山 区下志段味穴ヶ洞 2266-98
}

analysis. ${ }^{5)-8)}$ The Raman analysis of free carbon in ceramics before and after oxidation has never been carried out, although Raman analysis is a very important tool for observing carbon materials. Therefore, the Raman analysis of free carbon in oxidized products is fundamentally worth.

In this paper, we report the Raman characterization of the oxidation behavior of free carbon in tantalum- and niobiumcontaining silicon oxycarbide ceramics.

\section{Experimental}

Methyltriethoxysilane (MTES) was used as precursor silicon alkoxide (Shin-Etsu Chemical Co., Ltd.). The transition metal alkoxides used as inorganic sources were $\mathrm{Ta}\left(\mathrm{OC}_{2} \mathrm{H}_{5}\right)_{5}$ and $\mathrm{Nb}\left(\mathrm{OC}_{2} \mathrm{H}_{5}\right)_{5}$ (High purity Chemical Laboratory Co., Ltd.). These metal alkoxides and acethylacetone were mixed at a 1:2 molar ratio and stirred for $1 \mathrm{~h}$. The mixture of this modified metal alkoxide and MTES was stirred in ethanol (molar ratios; MTES $/$ metal alkoxide $=1 / 0.05$, MTES / ethanol $=1 / 3$ and MTES $\left./ \mathrm{H}_{2} \mathrm{O}=1 / 2\right)$. After mixing for $0.5 \mathrm{~h}$, the solution was poured into a Teflon dish and dried at $40^{\circ} \mathrm{C}$ and $80^{\circ} \mathrm{C}$ for $48 \mathrm{~h}$ and $200^{\circ} \mathrm{C}$ for $72 \mathrm{~h}$, to obtain self-supported hybrid films. The obtained hybrid films were heated to $1000^{\circ} \mathrm{C}$ at a heating rate of $3^{\circ} \mathrm{C} / \mathrm{min}$ and kept for $2 \mathrm{~h}$ in a flowing $\mathrm{Ar}$ atmosphere.

The oxidation test was carried out from room temperature to $1200^{\circ} \mathrm{C}$ under flowing dry air, using a thermogravimetric analyzer; Rigaku Thermo Plus. Oxidative heating rates of 1, 10 and $20^{\circ} \mathrm{C} / \mathrm{min}$ were applied.

${ }^{13} \mathrm{C}$-magic angle spinning nuclear magnetic resonance (MAS NMR) spectra were obtained by using JEOL JNMEXCALIBUR-270 MHz with a frequency of $67.80 \mathrm{MHz}$. Adamantane was used as an external standard. The sample spinning speed was approximately $6 \mathrm{kHz}$. The spectra of ${ }^{13} \mathrm{C}$-MAS NMR were recorded using a repetition time of $7.0 \mathrm{~s}$.

Raman spectra were measured using an Atago Raman system with an attached charge-coupled device (CCD). The laser 


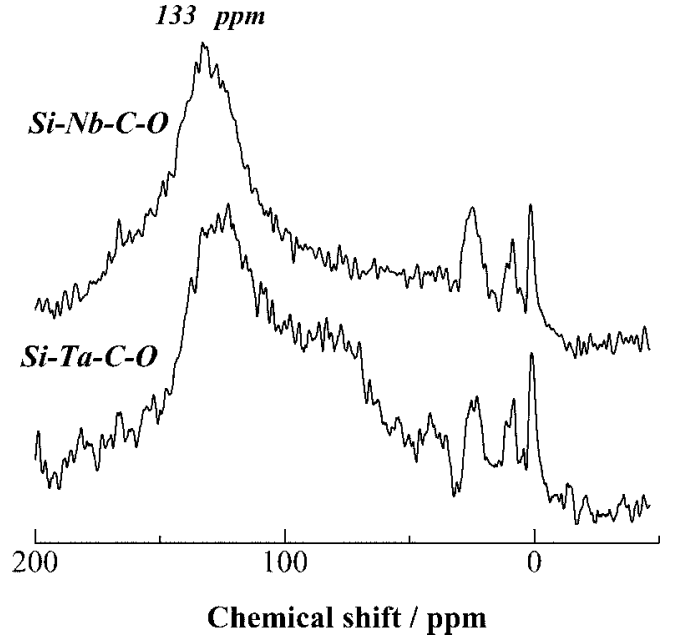

Fig. 1. ${ }^{13} \mathrm{C}-\mathrm{MAS}$ NMR spectra of tantalum- and niobium-containing silicon oxycarbide.

power was kept at $100 \mathrm{~mW}$. To obtain a good signal/noise ratio, 100 scans were carried out. A metallic silicon line was used for Raman shift calibration.

\section{Results and discussion}

Figure 1 shows the ${ }^{13} \mathrm{C}$-MAS NMR spectra of the obtained ceramics. Some resonance peaks were detected at approximately 15-30 ppm, which were due to the tetrahedral site $\mathrm{CSi}_{4}$. This corresponds to the ${ }^{29} \mathrm{Si}-\mathrm{NMR}$ results of our previous report $^{1)}$ and indicates that the rearrangement between $\mathrm{Si}-\mathrm{O}$ and $\mathrm{Si}-\mathrm{C}$ bonds occurred during pyrolysis, because the precursor hybrid was only composed of three siloxane bonds and methyl groups $\left(\mathrm{CH}_{3} \mathrm{SiO}_{1.5}\right)$. In polymethylsilsesquioxane-derived oxycarbide ceramics, no $\mathrm{Si}-\mathrm{O}-\mathrm{C}$ and $\mathrm{Si}-\mathrm{Si}$ bonds were confirmed. ${ }^{9)}$ The silicon atoms preferentially bond to oxygen and the remaining silicon atoms bond to carbon. Thus, the remaining carbon, namely excess carbon that has not bonded to other atoms, is defined as free carbon. The detailed pyrolysis behavior of hybrids has already been reported elsewhere. ${ }^{1)}$ The ${ }^{13} \mathrm{C}$-NMR spectra qualitatively show the presence of free carbon. As seen from the spectra, a very broad resonance peak detected at approximately $133 \mathrm{ppm}$ is assigned to $\mathrm{sp}^{2}$ carbon, the so-called free carbon, which is considered to be in tiny graphitic and amorphous state.

The Raman spectra of $\mathrm{Si}-\mathrm{Nb}-\mathrm{C}-\mathrm{O}$ and $\mathrm{Si}-\mathrm{Ta}-\mathrm{C}-\mathrm{O}$ ceramics before and after oxidation tests are shown in Figs. 2 and 3, respectively. The weight loss by oxidation showed only a slight difference among all the ceramics. We have already reported the oxidation behavior of $\mathrm{Si}-\mathrm{C}$ bonds determined by XPS, ${ }^{2)}$ although the oxidation behavior of free carbon was still unclear.

In the spectra, $\mathrm{D}$ and $\mathrm{G}$ peaks were detected at approximately 1360 and $1610 \mathrm{~cm}^{-1}$. These bands have already been reported for polycarbosilane-derived $\mathrm{SiC}$ fiber and silicon oxycarbide ceramics. ${ }^{4), 6), 10)-12 \text { ) }}$

$\mathrm{D}$ and $\mathrm{G}$ bands are normally observed at 1360 and 1580 $\mathrm{cm}^{-1}$, respectively. The $\mathrm{D}$ band is due to disordered carbons such as glassy carbon. More disordered carbons such as coke and charcoal show a broader band. In contrast, the $\mathrm{G}$ band is assigned to $\mathrm{C}=\mathrm{C}$ stretching vibration $(\mathrm{E} 2 \mathrm{~g})$, which is observed in this region for highly oriented pyrolitic graphite and natural single crystals of graphite.

The peak position of the $\mathrm{G}$ band was monitored at higher

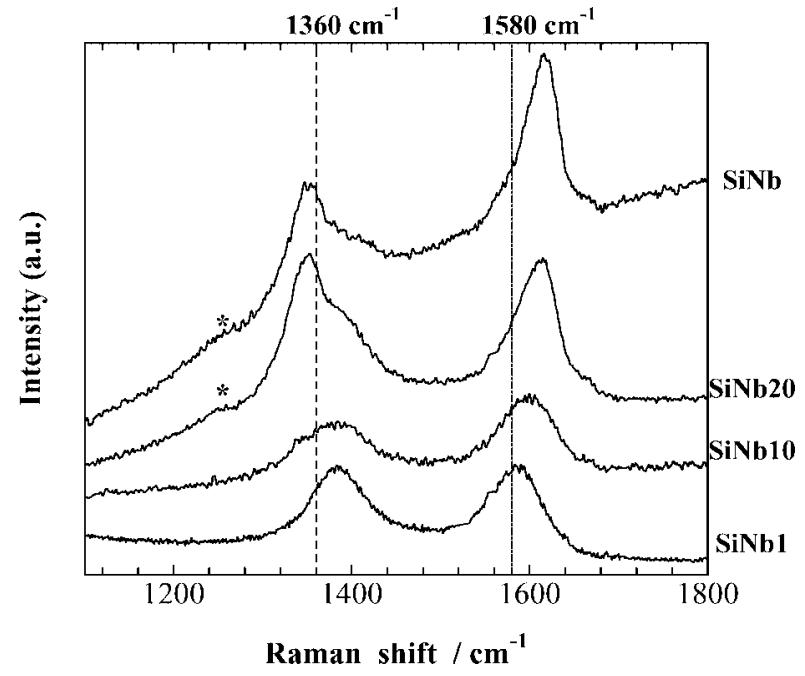

Fig. 2. Raman spectra of $\mathrm{Si}-\mathrm{Nb}-\mathrm{C}-\mathrm{O}$ ceramics before and after oxidation to $1200^{\circ} \mathrm{C}$. For the oxidized products of $\mathrm{Si}-\mathrm{Nb}-\mathrm{C}-\mathrm{O}$ ceramics, $\mathrm{SiNb} 20, \mathrm{SiNb} 10$ and $\mathrm{SiNb} 1$ are notated by heating rates of 20,10 and $1{ }^{\circ} \mathrm{C} / \mathrm{min}$.

Nonoxidized sample is described as $\mathrm{SiNb}$.

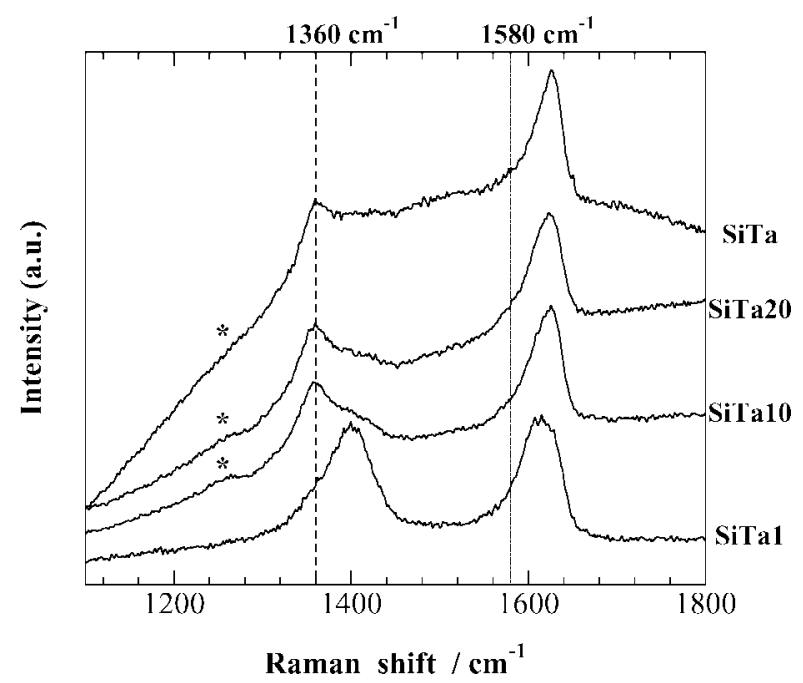

Fig. 3. Raman spectra of $\mathrm{Si}-\mathrm{Ta}-\mathrm{C}-\mathrm{O}$ ceramics before and after oxidation to $1200^{\circ} \mathrm{C}$. For the oxidized products of $\mathrm{Si}-\mathrm{Ta}-\mathrm{C}-\mathrm{O}$ ceramics, SiTa20, SiTa10 and SiTa1 are notated by heating rates of 20, 10 and 1 ${ }^{\circ} \mathrm{C} / \mathrm{min}$.

Nonoxidized sample is described as SiTa.

than $1580 \mathrm{~cm}^{-1}$ on the spectra before oxidation, which suggests mixed peaks of the $G$ and $D^{\prime}$ bands. ${ }^{13)}$ The peak at approximately $1610 \mathrm{~cm}^{-1}$ is defined as $\mathrm{D}^{\prime}$ band, suggesting tiny graphene layers with many edge carbon atoms, accompanying oxygen and/or radical species because the edge parts may cause partially localized $\pi$-electrons to shift to a higher frequency. ${ }^{13)}$ During the pyrolysis of hybrids, the organic methyl group is decomposed, resulting in the evolution of hydrogen and hydrocarbon gases. ${ }^{1), 3}$ In this decomposed stage, edge carbon atoms with accompanying oxygen and/or radical species may be formed.

More symmetrical bands and shifts to $1580 \mathrm{~cm}^{-1}$ in the spectrum of SiNb1 were confirmed, shown in Fig. 2. The sites such as the edge carbon with accompanying oxygen and radi- 
cal species may be reactive to oxidation.

On the other hand, the spectra of SiTa products before and after the oxidation test were different from those of $\mathrm{SiNb}$ products. The $\mathrm{G}$ band still remained unsymmetrical and at a position higher than $1580 \mathrm{~cm}^{-1}$ for SiTa1 and SiTa10, compared to that of Fig. 2. This suggests higher resistance to oxidation than a SiNb specimen. SEM images did not show any morphological differences (porosity etc.) among the obtained ceramics before and after the oxidation test. The difference of oxidation behavior between $\mathrm{SiNb}$ and $\mathrm{SiTa}$ suggests that tantalum oxide affects the oxidation of carbon, which prevents the evolution of surface oxygen components. This effect is consistent with tantalum oxide containing glassy carbon. ${ }^{14)}$

Additionally, G and D bands were superimposed on the large luminescence background in both spectra. After oxidation, the luminescence background became weaker. Babonneau and coworkers suggested that the luminescence background comes from carbon radical species. ${ }^{10)}$ This may be attributed to the oxidation of reactive sites such as radical carbon species.

An additional weak peak at approximately $1280 \mathrm{~cm}^{-1}$ was also observed after oxidation. Amorphous $\mathrm{SiO}_{2}$, when accompanied with nonbridging or partially ionized oxygen atoms, showed a Raman shift at approximately $1200 \mathrm{~cm}^{-1}$. $^{13)}$ This unstable inorganic bond disappeared under a low oxidative rate of $1^{\circ} \mathrm{C} / \mathrm{min}$.

\section{Conclusion}

Shaped oxycarbide ceramics were synthesized from a methyltriethoxysilane- and pentaethoxyniobium/tantalumbased hybrid. The oxidation behavior of free carbon in a transition metal containing oxycarbide ceramics was investigated. Free carbon was detected by ${ }^{13} \mathrm{C}-\mathrm{NMR}$ and Raman spectroscopy.

The Raman spectra of the specimens before oxidation showed G, D and D' bands, and luminescence background. However, the $\mathrm{D}^{\prime}$ band and background in the spectra of $\mathrm{Si}-\mathrm{Nb}-\mathrm{C}-\mathrm{O}$ ceramics disappeared after oxidation. This phenomenon could be related to the oxidation of the edge carbon with accompanying oxygen and/or radical species. In contrast, the spectra of $\mathrm{Si}-\mathrm{Ta}-\mathrm{C}-\mathrm{O}$ ceramics showed that the $\mathrm{G}$ band still remained to be asymmetric and mixed with $\mathrm{D}^{\prime}$ band at a position higher than $1580 \mathrm{~cm}^{-1}$ even after oxidation at a lower heating rate, which means the existence of edge carbon atoms. This strongly suggests a higher resistance to oxidation than a $\mathrm{Si}-\mathrm{Nb}-\mathrm{C}-\mathrm{O}$ specimen.

\section{References}

1) Fukushima, M., Yasuda, E., Nakamura, Y. and Tanabe, Y., $J$. Ceram. Soc. Japan, Vol. 111, pp. 857-859 (2003).

2) Fukushima, M., Yasuda, E., Nakamura, Y., Teranishi, Y., Nakamura, K. and Tanabe, Y., J. Ceram. Soc. Japan, Suppl., Vol. 112, pp. S1531-S1534 (2004).

3) Fukushima, M., Yasuda, E., Manocha, L. M., Manocha, S. M., Nakamura, Y., Akatsu, T. and Tanabe, Y., J. Ceram. Soc. Japan, Vol. 110, pp. 1044-1047 (2002).

4) Pantano, C. G., J. Sol-Gel Sci. Tech., Vol. 14, pp. 7-25 (1999).

5) Radovanovic, E., Gozzi, M. F., Goncalves, M. C. and Yoshida, I. V. P., J. Non-Cryst. Solids, Vol. 248, pp. 37-48 (2000).

6) Manocha, L. M., Yasuda, E., Tanabe, Y., Manocha, S. and Vashistha, D., Bull. Mater. Sci., Vol. 23, pp. 1-4 (2000).

7) Soraru, G. D. and Sutto, D., J. Sol-Gel Sci. Tech., Vol. 14, pp. 69-74 (1999).

8) Brewer, C. M., Bujalski, D. R., Parent, V. E., Su, K. and Zank, G. A., J. Sol-Gel Sci. Tech., Vol. 14, pp. 49-68 (1999).

9) Takamura, N., Taguchi, K., Gunji, T. and Abe, Y., J. Sol-Gel Sci. Tech., Vol. 16, pp. 227-234 (1999).

10) Soraru, G. D., Andrea, G. D., Campostrini, R., Babonneau, F. and Maritto, G., J. Am. Ceram. Soc., Vol. 78, pp. 379-387 (1995).

11) Ma, J., Shi, L., Shi, Y., Luo, S. and Xu, J., J. Appl. Polym. Sci., Vol. 85, pp. 1077-1086 (2002).

12) Sasaki, Y., Nishina, Y., Sato, M. and Okamura, K., J. Mater Sci., Vol. 22, pp. 443-448 (1987).

13) Nakamizo, M. and Tamai, K., Carbon, Vol. 22, pp. 197-198 (1984).

14) Tanabe, Y., Utsunomiya, M., Ishibashi, M., Kyotani, T., Kaburagi, Y. and Yasuda, E., Carbon, Vol. 40, pp. 1949-1955 (2002). 